Undas Vol 12., Nomor 2, Desember 2016 : 79--90

\title{
LEGENDA TELAGA BIDADARI DAN LEGENDA JAKA TARUB SEBUAH KAJIAN STRUKTURAL SASTRA BANDINGAN
}

\author{
Telaga Bidadari and Jaka Tarub Legends \\ A Structural Study on Comparative Literature \\ Agus Yulianto \\ Balai Bahasa Kalimantan Selatan \\ Jalan Jenderal Ahmad Yani Km 32,2, Loktabat, Banjarbaru 70712 Kalimantan Selatan \\ Telepon (0511) 4772641, Pos-el: agusb.indo@gmail.com
}

\begin{abstract}
Abstrak: Tujuan penelitian ini adalah untuk mengetahui persamaan dan perbedaan antara legenda Telaga Bidadari dari Kalimantan Selatan dengan cerita Jaka Tarub dari Jawa Tengah. Kajian yang digunakan dalam penelitian ini adalah kajian struktural sastra bandingan. Penelitian ini menggunakan meteode deskriptif-komparatif. Melalui kajian struktural sastra bandingan dapat diketahui bahwa dari segi struktur seperti tema, dan amanat terdapat kesamaan. Akan tetapi, dari segi tokoh dan penokohan, alur, dan latar terdapat perbedaan.
\end{abstract}

Kata kunci: Perbandingan, struktural, cerita rakyat.

Abstract: The aim of this research is to dig out the similarities and differences of Telaga Bidadari legend from South Borneo and Jaka Tarub legend from Central Java. This research uses structural literary comparative approach. With descriptive comparative method by using structural literary comparative approach it can be found out that theme and mandate are the same while character and characterization, plots and settings are different.

Key words: Comparative, structural, folklore

\section{PENDAHULUAN}

Cerita rakyat yang bertipe fairy tale yang mengisahkan tentang tujuh bidadari turun ke bumi untuk mandi ternyata banyak terdapat di daerahdaerah di Indonesia. Cerita-cerita tersebut boleh dikatakan memiliki banyak kesamaan, walaupun ada juga perbedaannya. Cerita fairy tale menurut Taumm (2011:86) adalah dongeng tentang peri yang meliputi: tantangan supranatural, istri atau suami atau kerabat supranatural, tugas-tugas supranatural, penolong supranatural, barang-barang magis, kekuatan atau pengetahuan supranatural, dan dongeng-dongeng lainnya tentang supranatural.

Salah satu cerita rakyat di Kalimantan Selatan yang mengisahkan tentang tujuh bidadari yang turun ke bumi untuk mandi adalah legenda Telaga Bidadari dari Kabupaten Hulu Sungai Selatan, Provinsi Kalimantan Selatan. Cerita legenda tersebut memiliki bukti fisik berupa telaga yang sampai saat ini masih ada di Kabupaten Hulu Sungai Selatan.

Cerita rakyat seperti Legenda Telaga Bidadari sangat terkenal pada 
zamannya. Akan tetapi, saat ini banyak generasi muda di Kalimantan Selatan yang tidak mengetahui lagi keberadaan cerita legenda Telaga Bidadari ini. Hal itu disebabkan makin berkembangnya cerita-cerita modern yang berbentuk novel atau cerpen. Baik novel dalam negeri maupun luar negeri.

Salah satu cerita rakyat yang mirip dengan cerita legenda Telaga Bidadari adalah cerita rakyat yang berjudul Jaka Tarub dari Jawa Tengah. Cerita ini sangat popular di daerahnya, bahkan di Indonesia. Kesamaan cerita antara legenda Telaga Bidadari dengan legenda Jaka Tarub membuat kedua cerita ini menjadi menarik untuk diperbandingkan. Dengan demikian masalah yang akan diangkat dalam penelitian ini adalah bagaimana perbandingan struktur cerita rakyat Telaga Bidadari dengan cerita rakyat Jaka Tarub bila ditinjau dari segi tema, tokoh dan penokohan, alur, latar dan amanat.

Berdasarkan teori sastra kontemporer, sebuah cerita yang mirip tidak dapat dikatakan cerita yang satu merupakan cerita yang terlebih dahulu ada dibandingkan cerita yang lain. Begitu juga sebaliknya. Oleh sebab itu, tidak dapat dikatakan bahwa cerita Jaka Tarub adalah cerita rakyat yang terlebih ada dibandingkan cerita legenda Telaga Bidadari atau sebaliknya. Dua buah cerita yang mirip hanya dapat diperbandingkan berdasarkan adanya perbedaan bahasa yang digunakan.

\section{KERANGKA TEORI}

Objek penelitian yang akan dibahas dalam tulisan ini adalah mengenai perbandingan cerita rakyat Telaga
Bidadari dari Kalimantan Selatan dengan Legenda Jaka Tarub dari Jawa berdasarkan kajian struktural.

Menurut Kurnia (1996:1-2) dalam kegiatan sastra bandingan terdapat beberapa pengertian, yaitu 1) sastra bandingan adalah kegiatan untuk mempelajari sastra lisan, terutama cerita rakyat dan penyebarannya serta menyelusuri waktu penulisan sastra lisan menjadi karya yang artistik, 2) sastra bandingan adalah kegiatan sastra yang menghubungkan dua kesusastraan atau lebih, dan 3) kegiatan sastra bandingan membicarakan sastra secara menyeluruh, sama dengan membicarakan sastra dunia, sastra universal, atau sastra umum.

Menurut Endraswara (2011:22) asumsi dasar sastra bandingan yang paling penting adalah: 1) hadirnya unsur tambahan atau pengurangan dalam karya sastra, 2) terjadinya persilangan kreativitas di otak pengarang, 3) pengarang adalah orang yang gemar meramu bacaan-bacaan masa silam, dan 4) pengarang tidak selalu suci, bersih, atau steril dari bacaan dan pengalaman masa lalu. Sastra bandingan di Indonesia terbagi menjadi empat kelompok, yaitu: 1) sastra bandingan dalam kaitan studi filologi yang dikenal sebagai kritik teks, 2) sastra bandingan dalam hubungan dengan sastra lisan, 3) sastra bandingan modern, dan 4) sastra bandingan interdisipliner.

Hakikat sastra bandingan menurut Sarman (2011:61) merupakan suatu upaya untuk meningkatkan pemahaman objek yang ditelaah. Untuk memahami karya sastra pada suatu kurun waktu, perlu dibandingkan suatu karya dengan 
karya yang lain sehingga ditemukan sifat-sifat yang sama atau berbeda antar karya tersebut dalam kurun waktu tertentu. Atau untuk memahami karya sastra pada kurun waktu yang berbeda diperlukan telaah sehingga ditemukan pula persamaan atau perbedaan antar karya sastra tersebut pada kurun waktu yang berbeda.

Menurut Nada (dalam Damono, 2005:4) menyebutkan bahwa yang merupakan hal penting bagi pengamat sastra itu adalah bahwa perbedaan bahasa merupakan salah satu syarat utama bagi sastra bandingan. Menurutnya, kajian yang hanya menyangkut satu bahasa tidak dapat disebut sastra bandingan. Dengan demikian, maka perbedaan antara bahasa adalah syarat untuk membangun kajian sastra bandingan.

Menurut Sapardi Djoko Damono (2005: 2) menyatakan bahwa sastra bandingan merupakan pendekatan dalam ilmu sastra yang tidak menghasilkan teori tersendiri. Dalam arti bahwa teori apapun dapat digunakan dalam penelitian sastra bandingan. Dalam hal ini berkaitan dengan pendapat pakar tersebut, maka teori yang digunakan sebagai alat pembandingnya adalah teori struktural.

Sesuai dengan namanya, teori struktural memandang dan memahami karya sastra dari segi struktur karya sastra itu sendiri. Menurut Teeuw (dalam Wiyatmi, 2006: 89) menyatakan bahwa karya sastra dipandang sebagai sesuatu yang otonom, berdiri sendiri, bebas dari pengarang, realitas, maupun pembaca.

Pada dasarnya penelitian struktural berangkat dari pendekatan objektif sebagaimana pendapat Abrams (Zaidan, 2002:20), yang menekankan karya sastra sebagai struktur yang bersifat otonom. Lebih lanjut Abrams (Tuloli, 2000:41) mengatakan, strukturalisme merupakan suatu sistem yang melihat suatu struktur lengkap dan saling menentukan dalam dirinya, di mana unsur-unsurnya saling berhubungan secara timbal-balik. Pradopo (2005:118) mengatakan, "analisis struktural adalah analisis yang melihat bahwa unsurunsur karya sastra saling berhubungan erat, saling menentukan artinya."

Menurut Mukarovsky (Tuloli, 2000:43) bahwa struktur adalah satuan yang terdiri atas bagian-bagian yang bersifat dinamis dan energenetik. Masing-masing bagian (unsur) mempunyai fungsi khas yang berhubungan dengan keseluruhan strukturnya. Menurut teori strukturalisme sastra, karya sastra merupakan "artefak", maka relasi-relasi struktural sebuah karya sastra hanya dapat dipahami dalam keseluruhan relasi unsur-unsur artefak itu sendiri (Taum, 1997:39).

Dengan demikian, melalui analisis struktural akan didapatkan makna keseluruhan dari karya sastra itu sendiri. Hal ini lebih dipertegas oleh Teeuw (Tuloli, 2000:43), bahwa analisis struktural bertujuan untuk membongkar dan memaparkan secermat, seteliti, semendetail, dan semendalam mungkin keterkaitan dan keterjalinan semua unsur dan aspek karya sastra yang bersama-sama menghasilkan makna keseluruhan. 


\section{METODE PENELITIAN}

Metode yang digunakan dalam penelitian ini adalah metode deskriptifkomparatif. Metode deskriptif adalah metode yang dilakukan dengan tidak menggunakan angka-angka, tetapi menggunakan penghayatan terhadap interaksi antar konsep yang sedang dikaji secara empiris (Semi, 1993:23). Dasar perbandingan yang dilakukan terhadap kedua cerita rakyat dilakukan berdasarkan perbedaan bahasa yang digunakan dalam kedua cerita.

Teknik penelitian dalam penelitian ini ditempuh melalui dua cara, yakni: (1) teknik pengumpulan data dan (2) teknik analisis data. Teknik pengumpulan data menggunakan teknik kepustakaan. Teknik analisis data dilakukan dengan tiga tahap: (1) menganalisis sturktur cerita rakyat Telaga Bidadari, menandai bagian-bagian yang merupakan unsur atau struktur cerita, dan menganalisis struktur cerita rakyat Telaga Biadadari (2) menganalisis cerita rakyat Jaka Tarub, menandai bagian-bagian yang merupakan unsur atau struktur cerita rakyat, dan menganalisis struktur cerita rakyat Jaka tarub (3) melakukan perbandingan berdasarkan hasil analisis struktur kedua cerita rakyat, mengambil simpulan dari hasil analisi data.

\section{ANALISIS DAN PEMBAHASAN}

\subsection{Sinopsis Cerita Telaga Bidadari}

Dahulu kala, ada seorang pemuda yang tampan dan gagah. Ia bernama Awang Sukma. Awang Sukma mengembara sampai ke tengah hutan belantara. Ia tertegun melihat aneka macam kehidupan di dalam hutan. Ia membangun sebuah rumah pohon di sebuah dahan pohon yang sangat besar.
Kehidupan di hutan rukun dan damai. Setelah lama tinggal di hutan, Awang Sukma diangkat menjadi penguasa daerah itu dan bergelar Datu. Sebulan sekali, Awang Sukma berkeliling daerah kekuasaannya dan sampailah ia di sebuah telaga yang jernih dan bening. Telaga tersebut terletak di bawah pohon yang rindang dengan buah-buahan yang banyak. Berbagai jenis burung dan serangga hidup dengan riangnya. "Hmm, alangkah indahnya telaga ini. Ternyata hutan ini menyimpan keindahan yang luar biasa," gumam Datu Awang Sukma.

Keesokan harinya, ketika Datu Awang Sukma sedang meniup serulingnya, ia mendengar suara riuh rendah di telaga. $\mathrm{Di}$ sela-sela tumpukan batu yang bercelah, Datu Awang Sukma mengintip ke arah telaga. Betapa terkejutnya Awang Sukma ketika melihat ada 7 orang gadis cantik sedang bermain air.

"Mungkinkah mereka itu para bidadari?" pikir Awang Sukma. Tujuh gadis cantik itu tidak sadar jika mereka sedang diperhatikan dan tidak menghiraukan selendang mereka yang digunakan untuk terbang, bertebaran di sekitar telaga. Salah satu selendang tersebut terletak di dekat Awang Sukma.

"Wah, ini kesempatan yang baik untuk mendapatkan selendang di pohon itu," gumam Datu Awang Sukma.

Mendengar suara dedaunan, para putri terkejut dan segera mengambil selendang masing-masing. Ketika ketujuh putri tersebut ingin terbang, ternyata ada salah seorang putri yang tidak menemukan pakaiannya. Ia telah ditinggal oleh keenam kakaknya. Saat itu, Datu Awang Sukma segera keluar dari persembunyiannya.

"Jangan takut tuan putri, hamba akan menolong asalkan tuan putri sudi tinggal bersama hamba," bujuk Datu Awang Sukma. Putri Bungsu masih ragu menerima uluran tangan Datu Awang Sukma. Namun karena tidak ada orang lain maka tidak ada 
jalan lain untuk Putri Bungsu kecuali menerima pertolongan Awang Sukma.

Datu Awang Sukma sangat mengagumi kecantikan Putri Bungsu. Demikian juga dengan Putri Bungsu. Ia merasa bahagia berada di dekat seorang yang tampan dan gagah perkasa. Akhirnya mereka memutuskan untuk menjadi suami istri. Setahun kemudian lahirlah seorang bayi perempuan yang cantik dan diberi nama Kumalasari. Kehidupan keluarga Datu Awang Sukma sangat bahagia. Namun, pada suatu hari seekor ayam hitam naik ke atas lumbung dan mengais padi di atas permukaan lumbung. Putri Bungsu berusaha mengusir ayam tersebut. Tiba-tiba matanya tertuju pada sebuah bumbung bambu yang tergeletak di bekas kaisan ayam. "Apa kira-kira isinya ya?" pikir Putri Bungsu. Ketika bumbung dibuka, Putri Bungsu terkejut dan berteriak gembira. "Ini selendangku!, seru Putri Bungsu. Selendang itu pun didekapnya erat-erat. Perasaan kesal dan jengkel tertuju pada suaminya. Tetapi ia pun sangat sayang pada suaminya. Akhirnya Putri Bungsu membulatkan tekadnya untuk kembali ke kahyangan. "Kini saatnya aku harus kembali!," katanya dalam hati. Putri Bungsu segera mengenakan selendangnya sambil menggendong bayinya.

Datu Awang Sukma terpana melihat kejadian itu. Ia langsung mendekat dan minta maaf atas tindakan yang tidak terpuji yaitu menyembunyikan selendang Putri Bungsu. Datu Awang Sukma menyadari bahwa perpisahan tidak bisa dielakkan. "Kanda, dinda mohon peliharalah Kumalasari dengan baik," kata Putri Bungsu kepada Datu Awang Sukma." Pandangan Datu Awang Sukma menerawang kosong ke angkasa. "Jika anak kita merindukan dinda, ambillah tujuh biji kemiri, dan masukkan ke dalam bakul yang digoncanggoncangkan dan iringilah dengan lantunan seruling. Pasti dinda akan segera datang menemuinya," ujar Putri Bungsu.
Putri Bungsu segera mengenakan selendangnya dan seketika terbang ke kahyangan. Datu Awang Sukma menatap sedih dan bersumpah untuk melarang anak keturunannya memelihara ayam hitam yang dia anggap membawa malapetaka.

\subsection{Sinopsis Cerita Jaka Tarub}

Legenda Jaka Tarub - Babad Tanah Jawi merupakan naskah sejarah Kesultanan Mataram. Cerita dimulai dengan menceritakan mengenai kisah seorang pemuda yang bernama Jaka Kudus, mengembara karena dimarahi ayahnya (KI Ageng Kudus). Singkat cerita, dalam pengembaraanya Jaka Kudus menikahi putri Ki Ageng Kembanglampir. Putri itu pun akhirnya meninggal saat melahirkan seorang bayi laki-laki.

Bayi laki-laki yang ditinggal mati ibunya itu, ditemukan seorang pemburu bernama Ki Ageng Selandaka. Si bayi digendong sambil mengejar burung sampai ke desa Tarub. Karena suatu hal, Ki Ageng Selandaka akhirnya meninggalkan bayi tersebut sendirian. Untunglah, si bayi ditemukan seorang janda, sebut saja Nyai Ageng Tarub, dan dijadikan anak angkat. Oleh penduduk sekitar ia dipanggil dengan nama Jaka Tarub.

Jaka Tarub tumbuh menjadi seorang pemuda yang gemar berburu. Suatu hari ia melanggar larangan ibu angkatnya supaya tidak berburu sampai kawasan Gunung Keramat. Di gunung itu terdapat sebuah telaga tempat tujuh bidadari mandi. Jaka Tarub mengambil selendang salah satu bidadari. Ketika acara mandi selesai, enam dari tujuh bidadari tersebut kembali ke kahyangan. Sisanya yang satu orang bingung mencari selendangnya, karena tanpa itu ia tidak mampu terbang. Jaka Tarub muncul datang menolong. Bidadari yang bernama Dewi Nawangwulan itu bersedia ikut pulang ke rumahnya. Keduanya akhirnya menikah dan 
mendapatkan seorang putri bernama Dewi Nawangsih.

Selama hidup berumah tangga, Nawangwulan selalu memakai kesaktiannya. Sebutir beras bisa dimasaknya menjadi sebakul nasi. Suatu hari Jaka Tarub melanggar larangan Nawangwulan supaya tidak membuka tutup penanak nasi. Akibatnya kesaktian Nawangwulan hilang. Sejak itu ia menanak nasi seperti umumnya wanita biasa. Maka, persediaan beras menjadi cepat habis. Ketika beras tinggal sedikit, Nawangwulan menemukan selendang pusakanya tersembunyi di dalam lumbung. Nawangwulan pun marah mengetahui kalau suaminya yang telah mencuri benda tersebut. Jaka Tarub memohon istrinya untuk tidak kembali ke kahyangan. Namun tekad Nawangwulan sudah bulat. Hanya demi bayi Nawangsih ia rela turun ke bumi untuk menyusui saja.

\subsection{Perbandingan Struktur Cerita Legenda Telaga Bidadari dan Legenda Jaka Tarub}

\subsubsection{Perbandingan Tema Cerita}

Mengenai tema cerita, Sudjiman (1988: 51) mengemukakan bahwa tema adalah gagasan, ide, atau pilihan utama yang mendasari suatu karya sastra. Sementara itu, Daiches dkk. (1986:827) mengatakan bahwa tema adalah makna karya sastra secara keseluruhan. Berdasarkan pengertian tema maka perbandingan tema dari kedua cerita tersebut dapat dikemukakan di bawah ini.

Tema dalam cerita Telaga Bidadari adalah tentang kesetiaan seorang istri terhadap keluarganya. Datu Awang Sukma adalah seorang manusia biasa yang berkat kecerdikannya dapat memperistri seorang bidadari. Putri
Bungsu adalah seorang bidadari dari kayangan. Dia bersama keenam saudaranya sering mandi di kolam yang ada di dalam hutan. Pada suatu hari Awang Sukma tidak sengaja mendapati ketujuh bidadari itu sedang mandi. Karena keisengannya, Awang Sukma menyembunyikan selendang bidadari yang paling muda yang bernama Putri Bungsu. Oleh sebab itu, Putri Bungsu tidak dapat terbang lagi pergi ke kayangan bersama keenam kakaknya. Putri Bungsu akhirnya menikah dengan Awang Sukma dan melahirkan seorang anak yang bernama Kumalasari. Pada suatu hari seekor ayam hitam datang mengais-ngais lumbung padi milik Awang Sukma. Secara tidak sengaja di kaki ayam hitam itu terkais bumbung tempat Awang Sukma menyembunyikan selendang Putri Bungsu. Putri Bungsu secara tidak sengaja juga melihat bumbung itu dan secara iseng membuka tutupnya. Betapa terkejut Putri Bungsu begitu mengetahui isi bumbung yang ternyata adalah selendang miliknya sendiri. Putri Bungsu menyadari akal bulus suaminya yang menyebabkan dia tidak dapat pergi ke kayangan. Setelah mendapatkan selendang, Putri Bungsu memutuskan untuk pergi kembali ke kayangan. Betapa sedih hati Awang Sukma menghadapi kenyataan tersebut. Akan tetapi, nasi sudah menjadi bubur dan keputusan Putri Bungsu tidak dapat lagi berubah. Dengan demikian Putri Bungsu kembali kekayangan. Akan tetapi, rasa sayang dan kesetiaan Putri Bungsu tidak hilang terhadap keluaraganya. Dia tetap akan kembali menemui suami dan anaknya dengan syarat Awang Sukma mengambil tujuh 
biji kemiri dan memasukkannya ke dalam bakul yang kemudian digoncanggoncangkan dan iringilah dengan lantunan seruling. Dengan demikian, pasti Putri Bungsu akan segera datang menemuinya.

Begitu juga dengan tema cerita yang terdapat dalam legenda Jaka Tarub adalah tentang kesetian seorang istri terhadap keluarganya. Jaka Tarub adalah manusia biasa yang berhasil memperistri seorang bidadari yang bernama Nawangwulan. Nawangwulan dapat diperistri Jaka Tarub akibat selendang yang dipakainya untuk terbang ke kayangan dicuri oleh Jaka Tarub. Perkawinan mereka dikaruniai seorang anak perempuan yang diberi nama Nawangsih. Suatu hari secara tidak sengaja Nawangwulan menemukan selendang di lumbung padi Jaka Tarub. Nawangwulan pun sadar terhadap akal bulus Jaka Tarub. Nawangwulan dengan kecewa memutuskan untuk kembali ke kayangan. Akan tetapi, Nawangwulan tetap bersedia untuk kembali ke bumi demi menyusui Nawangsih yang masih kecil. Kesetiaan Nawangwulan terhadap keluaraganya tetap tidak luntur walaupun mereka sudah tinggal di dua alam yang berbeda.

\subsubsection{Perbandingan Tokoh dan Penokohan}

Tokoh adalah individu rekaan yang mengalami peristiwa atau berlakuan dalam berbagai peristiwa dalam cerita (Sudjiman, 1988:16). Tokoh pada umumnya berwujud manusia, tetapi dapat juga berwujud binatang atau benda yang diinsankan sesuai dengan kehendak si pengarang. Penokohan adalah penyajian watak tokoh dan penciptaan citra tokoh (Sudjiman, 1988:23). Watak tokoh ialah kualitas tokoh, kualitas nalar dan jiwanya yang membedakannya dengan tokoh lain. Dengan gambaran ciri-ciri lahir dan sifat serta sikap batin, pembaca dapat mengenal watak masing-masing tokoh. Tokoh itu sendiri dapat dibedakan menjadi tokoh utama dan tokoh bawahan (pembantu). Tokoh utama adalah tokoh yang aktif dalam setiap peristiwa sedangkan tokoh bawahan adalah tokoh-tokoh yang membantu atau mendukung tokoh utama.

Tokoh utama dalam cerita legenda Telaga Bidadari adalah Datu Awang Sukma. Datu Awang Sukma digambarkan sebagai seorang pemuda yang tampan dan gagah perkasa. Datu Awang Sukma adalah seorang pemuda yang suka mengembara. Dia adalah orang yang kuat sehingga kemudian diangkat menjadi penguasa hutan. Selain itu, Awang Sukma juga digambarkan sebagai orang yang iseng dan jahil. Oleh sebab itu, Awang Sukma menyembunyikan selendang Putri Bungsu yang menyebabkannya tidak dapat terbang kembali ke kayangan. Akan tetapi, Awang Sukma juga digambarkan sebagai seorang suami yang setia dan mencintai keluarganya.

Tokoh utama dalam cerita Jaka Tarub adalah Jaka Tarub sendiri. Jaka Tarub digambarkan sebagai seorang pemuda yang senang berburu. Jaka Tarub juga memiliki sifat yang jahil dan iseng. Sifat jahil dan iseng jaka Tarub terlihat pada saat dia menyembunyikan selendang Nawangwulan yang menyebabkanya tidak dapat terbang ke kayangan. Selain itu, jaka Tarub juga digambarkan 
sebagai orang yang suka melanggar aturan. Aturan pertama yang dilanggarnya adalah larang ibunya untuk tidak berburu di kawasan Gunung Keramat. Aturan kedua yang dilanggarnya adalah larangan Nawangwulan untuk jangan membuka tutup penanak nasi. Akan tetapi, Jaka Tarub juga memiliki sikap yang setia dan menyayangi keluarganya.

Tokoh bawahan dalam cerita legenda Telaga Bidadari adalah Putri Bungsu dan putri Kumalasari. Putri Bungsu digambarkan sebagai bidadari yang sangat cantik. Selain itu, Putri Bungsu digambarkan juga sebagai istri yang setia dan seorang ibu yang sangat menyayangi anaknya. Hal itu dapat diketahui dari kenyataan bahwa meskipun Putri Bungsu telah kembali kekayangan tidak diceritakan bahwa dia menikah lagi. Selain itu, meskipun Putri Bungsu telah berada di Kayangan, dia tetap bersedia untuk kembali ke bumi untuk menyusui anaknya. Putri Kumalasari di dalam cerita hanya digambarkan sebagai seorang bayi perempuan berumur sepuluh tahun yang sangat cantik.

Tokoh bawahan dalam cerita Jaka Tarub adalah Nawangwulan dan Nawangsih. Nawangwulan adalah bidadari yang selendangnya dicuri oleh jaka Tarub yang menyebabkannya tidak dapat terbang kembali ke kayangan. Nawangwulan digambarkan sebagai seorang wanita yang sangat cantik. Selain itu, Nawangwulan juga digambarkan sebagai wanita yang setia dan sangat menyayangi keluarganya. Nawangsih hanya digambarkan sebagai anak yang berumur sepuluh tahun yang memiliki paras yang cantik.

\subsubsection{Perbandingan Alur Cerita}

Alur adalah urutan-urutan peristiwa yang membangun tulang punggung cerita (Sudjiman: 1988:29). Setiap peristiwa terjadi karena sebab akibat hingga penjelasannya sebagai akhir cerita itu. Sebuah cerita yang peristiwanya susul menyusul secara temporal dikatakan beralur terusan atau linear (maju). Alur yang menggunakan sorot balik dikatakan beralur balikan. Sementara itu, alur dikatakan datar apabila jalinan cerita di dalamnya hampir tidak terasa adanya gawatan dan leraian. Jika jalinan peristiwa dalam cerita itu semakin menanjak, sesuai dengan sifatnya alur itu, dikatakan beralur menanjak.

Pada dasarnya alur yang digunakan dalam cerita Telaga Bidadari dan cerita Jaka Tarub adalah sama-sama menggunakan alur maju, yaitu kisah diceritakan secara runtut dari awal sampai akhir tanpa ada cerita yang memflas back atau sorot balik. Namun, perbedaan ditemui di beberapa bagian cerita di antara kedua cerita tersebut. Perbedaan itu sudah terlihat pada awal cerita. Pada cerita Telaga Bidadari, awal cerita dimulai dari kesukaan Awang Sukma untuk mengembara. Pengembaraan Awang Sukma sampai masuk ke dalam hutan yang lebat. Di dalam hutan, Awang Sukma membangun rumah pohon dan bertempat tinggal di situ. Setelah beberapa lama tinggal di hutan, Awang Sukma diangkat menjadi penguasa dan bergelar datu. Sebulan sekali, Awang Sukma berkeliling di hutan kekuasaannya. Suatu kali saat berkeliling hutan, Awang Sukma 
menemukan tujuh bidadari sedang mandi ditelaga. Awang Sukma menyembunyikan selendang bidadari yang paling cantik bernama Putri Bungsu yang akhirnya menjadi istrinya karena tidak dapat kembali terbang ke kayangan.

Sementara itu, cerita Jaka Tarub dimulai dari pengembaraan Jaka Kudus karena dimarahi oleh ayahnya. Saat mengembara, Jaka Kudus bertemu dengan putri Ki Ageng Kembanglampir yang akhirnya menjadi istrinya. Istri Jaka Kudus meninggal dunia saat melahirkan anaknya. Anak Jaka Kudus akhirnya dipelihara oleh $\mathrm{Ki}$ Ageng Selandaka. Karena satu dan lain hal, anak Jaka Kudus ditingalkan sendirian di desa Tarub dan akhirnya dipelihara oleh Nyai Ageng Tarub. Jaka Tarub tumbuh menjadi seorang pemuda yang gemar berburu. Akan tetapi, Nyai Ageng Tarub melarang jaka Tarub untuk berburu di kawasan Gunung Keramat. Jaka Tarub melanggar larangan ibunya itu dan akhirnya dia bertemu dengan tujuh orang bidadari yang lagi mandi. Pada peristiwa bertemu dengan bidadari inilah terdapat perbedaan antara cerita Telaga Bidadari dengan cerita Jaka Tarub. Pada saat Awang Sukma bertemu dengan tujuh bidadari tidak ada satu larangan pun yang dilanggar sedangkan Jaka Tarub bertemu dengan tujuh bidadari karena melanggar larangan ibunya. Jaka Tarub menyembunyikan selendang salah satu bidadari yang bernama Nawangwulan yang akhirnya menjadi istrinya karena tidak dapat kembali ke kayangan.

Perbedaan lain yang terdapat dalam alur kedua cerita adalah pada saat Putri Bungsu dan Nawangwulan menemukan selendangnya. Pada cerita Telaga Bidadari, Putri Bungsu menemukan selendangnya di lumbung secara tidak sengaja karena kaisan seekor ayam hitam. Sementara itu, Nawangwulan menemukan selendangnya karena akibat Jaka Tarub melanggar larangan untuk tidak membuka penenak nasi. Akibat melanggar larangan Nawangwulan, persediaan padi semakin menipis. Oleh sebab itu, selendang Nawangwulan yang disembunyikan Jaka Tarub dibawah tumpukan padi akhirnya terlihat dan ditemukan oleh Nawangwulan.

Perbedaan lain juga terlihat diakhir kedua cerita. Pada cerita Telaga Bidadari, Putri Bungsu akhirnya kembali ke kayangan. Akan tetapi Putri Bungsu tetap bersedia turun ke bumi untuk menemui Awang Sukma dan Kumalasari dengan syarat Awang Sukma mengambil tujuh biji kemiri dan memasukkannya ke dalam bakul yang kemudian digoncang-goncangkan dan diiringi dengan lantunan seruling. Dengan demikian, pasti Putri Bungsu akan segera datang menemui mereka. Pada cerita Jaka Tarub, Nawangwulan juga kembali ke kayangan dan bersedia turun ke bumi untuk menyusui Nawangsih dengan syarat Jaka Tarub tidak boleh berada di tempat tersebut. Dengan kata lain, Nawangwulan tetap tidak mau bertemu dengan Jaka Tarub. Berdasarkan uraian alur di atas dapat disimpulkan bahwa terdapat perbedaan dan persamaan dalam pengaluran antara cerita Telaga Bidadari dan cerita Jaka Tarub. 


\subsubsection{Perbandingan Latar Cerita}

Tarigan (1984:136) mengemuka-kan latar adalah latar belakang fisik, unsur tempat dan ruang dalam suatu cerita. Dengan kata lain, segala keterangan, petunjuk, pengacuan yang berkaitan dengan waktu, ruang dan suasana terjadinya peristiwa dalam suatu karya sastra membangun latar cerita.

Latar tempat dalam cerita legenda Telaga Bidadari adalah di hutan dan di telaga serta di lumbung padi milik Awang Sukma. Tergambar pada saat Awang Sukma berjalan-jalan di hutan dan memergoki para bidadari sedang mandi di telaga. Selain itu, lumbung padi adalah tempat penyimpanan selendang Putri Bungsu yang disembunyikan oleh Awang Sukma. Latar tempat dalam cerita Jaka Tarub adalah di telaga, hutan Gunung Keramat, dan desa Tarub. Tergambar pada saat Jaka Tarub berburu di hutan Gunung Keramat dan berjumpa dengan para bidadari sedang mandi di telaga. Desa Tarub adalah tempat Jaka Tarub, ibunya, dan keluarganya bertempat tinggal.

Latar suasana dalam legenda Telaga Bidadari tergambar pada saat Awang Sukma menikmati suasana hutan. Rasa damai, tenang, dan riang menyelimuti suasana hutan. Suasana kebahagiaan juga terlihat saat Putri Bungsu menerima pinangan Awang Sukma yang gagah dan tampan. Akan tetapi, suasana kesedihan juga terasa dalam cerita saat Putri Bungsu akan kembali ke kayangan. Awang Sukma hanya bisa menyesali diri dan menatap kosong karena kesedihan hatinya. Latar suasana dalam cerita Jaka Tarub tergambar pada saat bidadari sedang mandi. Para bidadari begitu gembira bermain-main di telaga. Akan tetapi, suasana sedih juga tergambar pada saat Nawangwulan kehilangan selendang-nya dan Jaka Tarub kehilangan Nawangwulan karena kembali lagi ke kayangan. Suasana marah juga terdapat dalam cerita, yaitu saat Nawangwulan mengetahui jaka Tarublah yang menyembunyikan selendanganya.

Latar waktu dalam cerita legenda Telaga Bidadari dan Jaka Tarub adalah siang hari. Selain itu, hanya ada satu latar waktu yang terlihat jelas siang hari, yaitu pada cerita jaka Tarub ketika Nawangwulan setiap malam hari datang ke bumi untuk menyusui anaknya Nawangsih yang masih bayi.

\subsubsection{Perbandingan Amanat Cerita}

Amanat ialah ajaran moral atau pesan yang ingin disampaikan dalam karya sastra (Sudjiman, 1988:58). Amanat terdapat pada sebuah karya sastra dapat secara implisit atau eksplisit. Secara implisit, jika jalan keluar atau ajaran moral itu disiratkan dalam tingkah laku tokoh menjelang cerita berakhir dan secara eksplisit apabila pengarang pada tengah atau akhir cerita menyampaikan seruan, nasihat, anjuran, larangan, dan sebagainya berkenaan dengan gagasan yang mendasari cerita itu.

Amanat yang terdapat dalam cerita Telaga Bidadari dan Jaka Tarub hampir sama, yaitu setia dan sayang kepada keluarga. Rasa setia dan sayang itu tergambar dari sikap Putri Bungsu dan Nawangwulan kepada suami dan anaknya. 


\section{PENUTUP}

Cerita legenda Telaga Bidadari dan cerita Jaka Tarub adalah dua buah cerita rakyat yang memiliki banyak kesamaan dan juga perbedaan. Hal itu tidak berarti satu cerita rakyat menjiplak cerita rakyat yang lain.

Persamaan kedua cerita rakyat tersebut secara struktur terdapat pada tema. Tema yang terdapat dalam kedua cerita sama-sama tentang kesetiaan dan kasih sayang. Persamaan lain dari kedua cerita ini adalah sama-sama menceritakan tentang tujuh bidadari yang turun ke bumi untuk mandi di telaga dan salah satu bidadari tidak dapat kembali ke kayangan disebabkan kehilangan selendangnya. Selain itu, kesamaan yang terdapat dalam cerita terletak pada amanat, yaitu sama-sama tentang sikap setia dan sayang seorang istri kepada suami dan anaknya.

Adapun perbedaan antara kedua cerita adalah tentang tokoh dan penokohan, alur, dan latar. Penamaan tokoh yang berbeda. Watak tokoh juga ada perbedaan. Begitu juga alur seperti sebab ditemukannya selendang di kedua cerita berbeda. Perbedaan latar juga sangat jelas. Hal itu disebabkan perbedaan asal kedua cerita rakyat tersebut. Cerita legenda Telaga Bidadari dari Kalimantan Selatan dan cerita Jaka Tarub dari Jawa Tengah.

\section{DAFTAR PUSTAKA}

Daiches, David et al. 1968. English Literature. New York: Houghton Mifflin Company.

Damono, Sapardi Djoko. 2005. Pegangan Penelitian Sastra Bandingan. Jakarta: Pusat Bahasa.

Endraswara, Suwardi. 2011. Metodologi Penelitian Sastra Bandingan. Jakarta: Bukupop.

Kurnia, Sayuti. 1996. Sastra Bandingan. Jakarta: Departemen Pendidikan dan Kebudayaan.

Pradopo, Rahmat Djoko. 2005. Pengkajian Puisi. Yogyakarta: Gajah Mada University Press.

Sarman. 2011.Tokoh Legendaris dalam sastra Lisan Sulawesi Tengah. Multilingual volume 1 tahun x edisi Juni 2011). Palu: Balai Bahasa Sulawesi Tengah.

Semi. M. Atar. 1993. Anatomi Sastra. Padamg: Angkasa.

Sudjiman, Panuti. 1988. Memahamai Cerita Rekaan. Jakarta: PT Dunia Pustaka Jaya.

Tarigan, Henry Guntur. 1984. Prinsip-prinsip Dasar Sastra. Bandung: Penerbit Angkasa.

Taum, Yoseph Yapi. 1997. Pengantar Teori Sastra: Ekspresivisme, Strukturalisme, Pascastrukturalisme, Sosiologi, Resepsi. Ende: Nusa Indah. 
Legenda Telaga Bidadari dan Legenda Jaka Tarub Sebuah Kajian Struktural Sastra Bandingan (Agus Yulianto)

2011. Studi Sastra Lisan: Sejarah, Teori, Metode dan Pendekatan Disertai Contoh Penerapannya. Yogyakarta: Lamalera.

Tuloli, Nani. 2000. Teori Fiksi. Gorontalo: BMT.

Wiyatmi. 2006. Pengantar Kajian Sastra. Yogyakarta: Pustaka.

Zaidan, Abdul Rozak dkk. 2007. Kamus Istilah Sastra. Jakarta: Balai Pustaka. 